Biljana Stojanović*

UDK 371.695:159.955.6-053.5

Fakultet pedagoških nauka

371.382:159.955.6-053.5

Univerziteta u Kragujevcu

Fakultet u Jagodini

DOI: 10.19090/gff.2018.2.135-149

Originalni naučni rad

\title{
MOGUĆNOSTI RAZVIJANJA ANALITIČKO-SINTETIČKOG MIŠLJENJA UČENIKA PRIMENOM SISTEMA DIDAKTIČKIH IGARA**
}

Cilj ovog istraživanja je bio da se ispita mogućnost podsticanja razvoja analitičkosintetičkog mišljenja učenika primenom sistema didaktičkih igara. Istraživački dizajn je podrazumevao primenu eksperimenta sa paralelnim grupama na uzorku 163 učenika prvog razreda osnovne škole (6,5-7,5 godina). Primenjeni instrument je Kosov test sastavljanja kocki koji meri analitičko-sintetičku sposobnost mišljenja. Rezultati istraživanja pokazali su da sistem didaktičkih igara nije značajno uticao na sposobnost analitičko-sintetičkog mišljenja učenika na datom uzorku jer se između učenika kontrolne i eksperimentalne grupe $\mathrm{u}$ finalnom ispitivanju nije pojavila statistički značajna razlika. S obzirom na to da su, ipak,zabeleženi i pozitivni efekti primenjenog postupka kod učenika eksperimentalne grupe, kao što su ukupna atmosfera na času, zadovoljstvo učenika, visoka motivacija za rad, bogatija komunikacija i dr., zaključeno je da je potrebno razmotriti primenu igre u realizaciji nastavnih sadržaja, posebno u mlađim razredima osnovne škole.

Ključne reči: analitičko-sintetičko mišljenje; nastava; sistem didaktičkih igara; učenik.

\section{UVOD}

Brojni psiholozi i pedagozi koji su proučavali razvojne pojave u ranom detinjstvu, utvrdili su da je moguće uticati na razvoj misaonih sposobnosti dece, naročito ako se način prilagodi dečjim potrebama i interesovanjima koji se menjaju sa uzrastom i vrstama aktivnosti koje privlače decu (Thomas - Warren, \& de Vries, 2011; Cutter-Mackenzie- Edwards-Moore, \& Boyd, 2014; Maričić - Špijunović, \& Lazić, 2016).

Važna karakteristika misli deteta na početku školovanja jeste mogućnost da dete na novi način objašnjava, uspostavlja veze i utvrđuje odnose među pojavama $\mathrm{i}$ predmetima. Počevši od 7. godine, deca mogu analitičko-sintetičkim putem da

\footnotetext{
*biljanastojanovic23@yahoo.com

** U radu su korišćeni rezultati doktorske disertacije "Primena sistema didaktičkih igara u procesu razvoja misaonih sposobnosti učenika na mladjem školskom uzrastu” odbranjene (2014.) na Filozofskom fakultetu Univerziteta u Novom Sadu.
} 
objašnjavaju postupke, da razlažu određenu pojavu ili predmet na niz njegovih svojstava i da spajaju elementarna, jednostavna svojstva u šire celine. Deca su na ovom uzrastu dostigla dva suštinska razvojna postignuća. Kao prvo, sposobna su da formiraju klase objekata, da izdvajaju jedno obeležje zajedničko svim objektima i da ga dosledno sprovode kao kriterijum svrstavanja u klasu. Drugo postignuće je sposobnost da formiraju, bar minimalni, sistem pojmova. Na ovom uzrastu deca su sposobna da shvate logičke odnose podređenih i nadređenih klasa, barem na dva nivoa opštosti, te da izvode odgovarajuće logičke operacije (Ivić - Pešić, \& Antić, 2001). Rubinštajn (1981) navodi da se razvoj mišljenja učenika ne može ni zamisliti ako ih ne osposobljavamo za samostalno rasuđivanje, za vršenje analize, sinteze, upoređivanja i uopštavanja, koji zahtevaju rešavanje svakog problema. Zadatak mišljenja je da raščlani raznovrsna uzajamna delovanja, da za svako od njih pronađe i izdvoji bitne momente, zatim da, upoređivanjem i uzajamnim povezivanjem apstrakcija do kojih mišljenje na taj način dolazi, misaono oživi sliku stvarnosti u svoj njenoj konkretnosti. To otvara pitanje na koji način i kojim postupcima je moguće podsticati razvoj misaonih sposobnosti na mlađem školskom uzrastu. Jukić (2005) navodi da razvoj analitičko-sintetičkog mišljenja učenika zavisi od strukture i vrste nastavnog gradiva, od uzrasta učenika, od koncepcije organizacije nastavnog časa i od raspoloživih nastavnih sredstava i metoda.

Jedna od omiljenih aktivnosti dece, naročito na mlađem školskom uzrastu, svakako je igra (Wood, 2010; Pribišev Beleslin, 2013), što otvara pitanje na koji način je sistematski upotrebiti u didaktičke svrhe (Johnson \& Patte, 2013). Korišćenje didaktičkih igara na početku školovanja može biti od velike koristi za učenike jer su uskladjene sa učeničkim razvojnim mogućnostima i interesovanjima. $\mathrm{U}$ tom smislu, mnogi autori smatraju da je neophodno implementirati igru u zvanične nastavne planove i programe i obučiti nastavnike da koriste igru kao efikasno sredstvo za učenje (Pramling \& Pramling 2013; Pribišev Beleslin, 2013).

Igra se često posmatra u razvojnoj liniji sa mišljenjem i učenjem. Pijaže, na primer, igru shvata kao asimilaciju dečjeg iskustva u njegovu shemu sveta, te preko promena u načinima igranja identifikuje stadijume intelektualnog razvoja. Prema Pijažeu, isti faktori koji određuju intelektualni razvitak određuju i razvitak igre. Tako je igra fenomen koji prati razvoj intelektualnih funkcija i reflektuje glavne karakteristike pojedinih etapa (Lillard, 2014). Za razliku od predškolskog perioda, igra se u školskom uzrastu prenosi na unutrašnje procese, unutrašnji govor, logičko pamćenje i apstraktno mišljenje. U školskom uzrastu igra ne umire, već prodire u odnos prema stvarnosti. Ona ima svoje unutrašnje produženje u školskoj nastavi i radu. Pijaže navodi tri vrste igara, koje odgovaraju trima stadijumima, odnosno 
trima sukcesivnim oblicima inteligencije (senzomotornom, reprezentacionom i refleksivnom). To su praktične igre, simboličke igre i igre sa pravilima (Kamenov, 2010). Dok Pijaže (Piaget \& Inhelder, 1978) razmatra tri vrste igara koje odgovaraju različitim fazama mentalnog razvoja, Vigotski je fokusiran samo na jednu vrstu, simboličnu igru. Vigotski (1978) objašnjava da je simbolička igra aktivnost u kojoj deca prvi put shvataju da akcije (i objekti na kojima se vrši) mogu biti odvojene od realnosti (Tejlor, 2013; Lillard \& Voollei, 2014; Lillard, 2014). Na taj način igra doprinosi razvoju viših mentalnih funkcija i promoviše namerno ponašanje. To postaje moguće zbog odnosa koji postoji između igre i pravila koja moraju da je prate (Petrović Sočo, 2014; Bodrova \& Leong, 2015).

Mnogobrojna istraživanja su se bavila uticajem igre na razvoj misaonih sposobnosti učenika. Salc, Dikson i Džonson (Saltz - Dixon, \& Johnson, 1977) istraživali su uticaj igre na razvoj kognitivnih funkcija i došli do zaključka da je primena igara doprinela matematičkom obrazovanju učenika. Druga istraživanja su pokazala da je igra značajno uticala na sposobnost reprezentacije (Pederson - RookGreen, \& Elder, 1981), rešavanje problema (Smith \& Dutton, 1979) i sl. Longitudinalna studija Bergena i Mauera (Bergen \& Mauer, 2000) pokazala je da su deca koja su se igrala materijalima za učenje čitanja u predškolskom uzrastu kasnije, u školi, spontano čitala i imala bolju sposobnost verbalizacije. Koristeći slične strategije, Kuk (Cook, 2000) je obogatio dečju igru brojnim simbolima i našao da bogata sredina aktivira govor kod dece i razvija matematičke pojmove. Slične rezultate pokazalo je i istraživanje u oblasti matematičkih znanja (Wolfang Stannard, \& Jones, 2001). Rezultati navedenih istraživanja sugerišu da igra nije samo jedan aspekt života koji donosi radost, zabavu i značenje. Ona je element za sebe, ali je i temelj učenja i razvoja dece tokom celog života (Mishra - Koehler, \& Henriksen, 2011; Konklin, 2014). Istraživanja fenomena igre ukazuju na njen značaj u smislu podsticanja intrinzične motivacije kod deteta, jačanja samokontrole, usmeravanja njegove pažnje i ponašanja (Platz \& Arellano 2011; Wood, 2013; Cutter - Mackenzie et al., 2014). Pri tome, procesi igre dovode do stvaranja novih mentalnih struktura, kroz rešavanje problemskih situacija, razvijaju se i usavršavaju misaone sposobnosti. Igre se uvršćuju u aktivnosti uviđanja, klasifikovanja, koordiniranja, oprobavanja, pamćenja i korišćenja tih informacija, pri čemu poprimaju oblik ispitivanja i manipulisanja objektima da bi se izazvale promene, zbog čega se određuju kao oblik istraživanja i sakupljanja informacija (Millar, 1972).

S obzirom na primenjeni eksperimentalni program u ovom istraživanju, važno je da objasnimo posebnu vrstu igara, didaktičke igre. Specifičnost didaktičke igre se ogleda u njenoj pedagoškoj usmerenosti. Didaktička igra predstavlja 
situaciju u kojoj se za učenika javljaju intelektualni problemi koje ne može, ili može samo delimično, da reši na osnovu ranijih iskustava. "Napor koji pri tom ulaže u rešavanje, omogućen visokom motivacijom koju igra sadrži, osnovna je poluga razvojnog delovanja na inteligenciju" (Kamenov, 1989: 83). Ova vrsta igre često je povezana sa razvojem misaonih sposobnosti i sposobnosti improvizacije - koje dovode do "mentalne gipkosti" (Kray \& Ferdinand, 2013).

Didaktičke igre koje su primenjene u ovom istraživanju imale su funkciju da učenicima omoguće sticanje iskustava i razvoj sposobnosti interiorizacije logičkih sistema klasifikacije, serijacije, transformacije poretka i verovatnoće. "Pojmovi, koje dete formira u didaktičkoj igri omogućavaju mu organizaciju i sistematizaciju čulnog iskustva, pomažu mu da zaključuje sistematično, a čulno iskustvo da misli u slikama, što se odražava na samostalnost i originalnost rešenja do kojih dođe" (Kamenov, 2010: 42). Jedna od karakteristika igre deteta na mlađem školskom uzrastu jeste sposobnost misaonog raščlanjavanja realnih predmeta, procesa i pojava na njihove sastavne delove, na razna svojstva tih delova, što podrazumeva procese analize i sinteze.

Polazeći od značaja igre i njenih formativnih mogućnosti, smatramo opravdanim istraživanje kojim želimo da ispitamo da li je i u kojoj meri moguće uticati na razvijanje analitičko-sintetičkog mišljenja učenika primenom sistema didaktičkih igara.

\section{METODOLOGIJA ISTRAŽIVANJA}

Cilj i zadaci istraživanja. Cilj istraživanja je ispitivanje mogućnosti da se primenom didaktičkih igara u nastavi utiče na razvoj analitičko-sintetičkog mišljenja učenika kroz postignuća na Kosovom testu sastavljanja kocki. U skladu sa ciljem postavljeni su sledeći istraživački zadaci: 1) Utvrditi da li i u kojoj meri sistem didaktičkih igara utiče na sposobnost analitičko-sintetičkog mišljenja učenika prvog razreda; 2) Ispitati da li postoje statistički značajne razlike u razvijenosti misaonih sposobnosti između učenika eksperimentalne grupe koji su bili izloženi uticaju sistema didaktičkih igara i učenika kontrolne grupe sa kojima je realizovan redovni nastavni program na uobičajen način. Kao rezultat istraživanja očekuje se naučna potvrda opravdanosti primene sistema didaktičkih igara $u$ programu prvog razreda osnovne škole.

Uzorak. U toku istraživanja ispitani su učenici uzrasta od 6,5 do 7,5 godina. Ispitano je 163 učenika prvog razreda - 4 odeljenja u Osnovnoj školi "17. oktobar" i 2 odeljenja u Osnovnoj školi "Rada Miljković”u Jagodini. Uzorak je prigodan. Prikaz uzorka dat je u tabeli 1. 
Tabela 1. Eksperimentalna i kontrolna grupa s obzirom na školu koju pohađaju

\begin{tabular}{llll}
\hline \multirow{2}{*}{ Grupa u kojoj se nalaze ispitanici } & \multicolumn{2}{c}{ Škola koju pohađaju učenici } & ukupno \\
\cline { 2 - 4 } & OŠ “17. oktobar” & OŠ “Rada Miljković” & \\
\hline eksperimentalna & 54 & 28 & 82 \\
\hline kontrolna & 53 & 28 & 81 \\
\hline ukupno & 107 & 56 & 163 \\
\hline
\end{tabular}

Instrument. Za ispitivanje je korišćen Kosov test sastavljanja kocki. Kos (Kohs, 1923) je za test upotrebio različito obojene drvene kocke, čime je osigurao interes dece. Ovaj test je merio analitičko-sintetičku delatnost. Za uspešno sastavljanje / rešavanje zadataka ispitanik je morao prvo analizirati uzorak u sastavne delove i zatim sintetizovati utiske u pravilnu reprodukciju uzorka putem kocki.

Postupak ispitivanja. Istraživanje je realizovano tokom školske 2015/16.godine u periodu oktobar 2015 - jun 2016. godine. Četiri odeljenja učenika škole "17. oktobar", (107 ispitanika) i dva odeljenja škole "Rada Miljković" (56 ispitanika) bila su podeljena na kontrolnu (K) i eksperimentalnu (E) grupu. U oktobru je izvršeno inicijalno merenje u kontrolnoj i eksperimentalnoj grupi uz pomoć Kosovog testa sastavljanja kocki. Grupe učenika bile su ujednačene na osnovu inicijalnog testa izračunavanjem aritmetičke sredine (mere proseka) i standardne devijacije (mere varijabilnosti $\mathrm{E}-\mathrm{SD}=11,59 ; \mathrm{K}-\mathrm{SD}=10,95$ ) za svaku grupu ispitanika. U eksperimentalnu grupu uveden je eksperimentalni programsistem didaktičkih igara, koji je posebno izrađen za svrhu ovog istraživanja.

Eksperimentalni program - sistem didaktičkih igara. Opšti postupak razvijanja analitičko-sintetičkog mišljenja koji je sadržan u određenim igrama sadrži sledeće: obavljanje niza radnji koje u materijalizovanom i eksteriorizovanom obliku sadrže u sebi oslonac za misaone operacije koje vode istaknutom cilju, uz odgovarajuće postupke analize i sinteze, indukcije i dedukcije (vrše se poređenja, uočavaju sličnosti i razlike, razdvaja bitno od sporednog). Da bi se ostvarili navedeni zadaci, sistem didaktičkih igara sadržavao je sledeće grupe igara: igre koje sadrže induktivne aktivnosti, operacije geometrijskim oblicima, igre koje sadrže uopštavanje i klasifikovanje, igre koje sadrže shvatanje i formiranje pojmova i igre i aktivnosti koje uključuju rezonovanje. Kriterijumi prema kojima su igre birane su sledeći: omogućavanje učenicima da steknu iskustvo na čijoj osnovi treba da dođe do interiorizacije logičkih sistema klasifikacije, serijacije, transformacije poretka i verovatnoće; postojanje redosleda operacija u igrama koje omogućavaju akceleraciju i amplifikaciju razvoja; podsticanje učenika na aktivnost, negovanje samostalnosti i poverenja u sopstvene snage; razvijanje analitičkog i intuitivnog 
mišljenja; podsticanje divregentnog mišljenja putem rešavanja problema $u$ situacijama kada ne mogu da pronađu gotova rešenja na osnovu prethodnog znanja i iskustva. Jedan od kriterijuma je bio da u igrama postoji otežavanje zadataka ograničavanjem vremena potrebnog za rešavanje zadatka ili povećanjem broja kriterijuma i broja logičkih koraka koje treba uzeti u obzir da bi se došlo do rešenja. Posebna grupa otežavanja zadataka odnosila se na prelaženje sa manipulativnog, perceptivnog rešavanja problema na rešavanje na mentalnom planu anticipiranjem rešenja i njihovom proverom na osnovu logičke konsekventnosti I analize situacije.

Tok ispitivanja. Realizovanje nastavnog programa putem sistema didaktičkih igara trajalo je 6 meseci. Učitelji su u eksperimentalnoj grupi primenjivali sistem didaktičkih igara 3-4 puta nedeljno u izvođenju svih nastavnih predmeta $\mathrm{i}$ to podjednako na časovima sa ciljem obrade, utvrđivanja i obnavljanja gradiva. U kontrolnoj grupi nastavni plan i program realizovan je prema redovnom planu aktivnosti. Ponovno testiranje učenika obavljeno je šest meseci nakon sprovedenog eksperimentalnog programa istim instrumentom kao u inicijalnom ispitivanju, odnosno ustanovljena je razlika između inicijalnog stanja (stanja pre delovanja eksperimentalnog faktora) i finalnog stanja (stanje posle dejstva tog faktora).

\section{REZULTATI ISTRAŽIVANJA}

Da bismo ispitali mogućnost uticaja sistema didaktičkih igara na razvoj analitičko-sintetičkog mišljenja učenika prvog razreda, koristili smo Kosov test sastavljanja kocki ${ }^{1}$. Za uspešno sastavljanje, rešavanje zadataka ispitanik mora prvo analizirati uzorak u sastavne delove $\mathrm{i}$ zatim sintetizovati utiske $\mathrm{u}$ pravilnu reprodukciju uzorka putem kocki.

Rezultati koje smo dobili u inicijalnom testiranju pokazali su da su kontrolna i eksperimentalna grupa ujednačene u postignućima na ovom testu.

\footnotetext{
${ }^{1}$ Kos je upotrebljivost testa od ispitivanja analitičko-sintetičkog mišljenja proširio na ispitivanje opšte inteligencije. Izračunao je korelacije među postignućima ispitanika koje je uključio u uzorak za standardizaciju svoje skale inteligencije i na Stanford-Bine skali. Na osnovu korelacije, zaključio je da oba testa, uprkos suštinskoj različitosti materijala, obuhvataju u osnovi iste mentalne funkcije.
} 
Tabela 2. Kosov test sastavljanja kocki ( inicijalno testiranje)

\begin{tabular}{ccc}
\hline \multicolumn{3}{c}{ t-test for Equality of Means } \\
\hline $\mathrm{T}$ & $\mathrm{df}$ & Sig. (2-tailed) \\
\hline$-0,990$ & 161 & 0,324 \\
\hline
\end{tabular}

T-test (tabela 2) i vrednosti $\mathrm{df}=161 \mathrm{i} \mathrm{p}=0,324$ ukazuju na to da su u inicijalnom testiranju učenici ujednačeni kada je reč o postignućima na testu Kosovog testa sastavljanja kocki.

Posle primenjenog sistema didaktičkih igara $\mathrm{u}$ eksperimentalnoj grupi izvršeno je finalno merenje na testu slaganja Kosovih kocki. Dobijeni su sledeći rezultati: vrednosti aritmtetičke sredine za eksperimentalnu grupu $(\mathrm{AS}=29,84)$ i za kontrolnu grupu $(\mathrm{AS}=28,73)$ pokazuju da su u postignućima obe grupe približne. Rezultati su prikazani u tabeli 3.

Tabela 3. Kosov test slaganja kocki (finalno testiranje)

\begin{tabular}{llr}
\hline Grupa u kojoj se nalazi ispitanik & & \multicolumn{1}{c}{ Statistic } \\
\hline eksperimentalna & Mean & 29,84 \\
\cline { 2 - 3 } & Std. Deviation & 11,65 \\
\cline { 2 - 3 } & Minimum & 6,00 \\
\cline { 2 - 3 } & Maximum & 52,00 \\
\hline \multirow{2}{*}{ kontrolna } & Mean & 28,73 \\
\cline { 2 - 3 } & Std. Deviation & 11,05 \\
\cline { 2 - 3 } & Minimum & 3,00 \\
\cline { 2 - 3 } & Maximum & 54,00 \\
\hline
\end{tabular}

Dalja analiza rezultata finalnog testiranja vršena uz pomoć $\mathrm{t}$-testa $(\mathrm{t}=0,626$, $\mathrm{df}=161, \mathrm{p}=0$, 532) pokazala je da su učenici eksperimentalne i kontrolne grupe ujednačeni, odnosno da ne postoji razlika u postignućima, iako je u eksperimentalnoj grupi bio primenjen sistem didaktičkih igara (tabela 4).

Tabela 4. Kosov test sastavljanja kocki (finalno testiranje)

\begin{tabular}{ccc}
\hline \multicolumn{3}{c}{$\mathrm{t}$-test for Equality of Means } \\
\hline $\mathrm{t}$ & $\mathrm{df}$ & Sig. (2-tailed) \\
\hline 0,626 & 161 & 0,532 \\
\hline
\end{tabular}




\section{DISKUSIJA}

Rezultati koje smo dobili ukazuju na to da nema statistički značajne razlike među učenicima eksperimentalne i kontrolne grupe i da sistem didaktičkih igara nije značajno doprineo razvoju analitičko-sintetičkog mišljenja učenika. Po našem mišljenju, postoji više razloga za rezultate koje smo dobili na datom uzorku. Prvi razlog se svakako odnosi na karakteristike mišljenja učenika prvog razreda. Alogičnost dečjeg mišljenja ogleda se u sledećim činjenicama: kod učenika na ovom uzrastu javlja se odsustvo logičke povezanosti u izlaganju, kao i odsustvo potrebe da izlažu i obrazlažu svoja mišljenja. Takođe, učenici često olako izvode zaključke na osnovu pojedinačnih slučajeva - nisu u mogućnosti da se stave na stanovište sabesednika, da prime i logički operišu sudovima koji su samo hipotetički itd. (Ivić, 1964).

U skladu sa tim, Luria (1976) objašnjava princip po kome mišljenje funkcioniše prilikom rešavanja testa Kosove kocke. Ispitanik treba da sagradi konstrukciju čija mu se shema pokazuje u obliku crteža odvojenih blokova. To znači da on ima zadatak da raščlani, izdvoji bitne trenutke, zatim da upoređivanjem i uzajamnim povezivanjem apstrakcija misaono oživi sliku stvarnosti u njenoj konkretnosti. Pomenuti procesi mogu objasniti probleme koje su učenici imali prilikom rešavanja zadataka na ovom testu.

U ovom delu ukazaćemo na načine na koje su učenici pristupali rešavanju postavljenih zadataka u testu slaganja kocki. Na početku ispitivač daje verbalno obrazloženje načina na koji treba slagati kocke, a zatim učenici na osnovu uvida u karton sa modelom treba da naprave istu figuru na svojim kockicama. Problemi su se javili na ovom nivou kada su učenici samostalno počeli da formiraju sliku koja je zadata. Neki učenici $(14 \%)$ su već na početnim slikama primenjivali princip slaganja prema celini. Naime, oni su pokušavali da naprave figuru sa slike, koristeći cele kockice. Samim tim bili su vrlo brzo suočeni sa problemom da im nedostaju kockice. Posle više pokušaja i pogrešaka uspevali su da shvate princip slaganja kocki. Najveći broj učenika (72\%) je posle određenog vremena za razmišljanje uviđao princip uklapanja, što znači da su analizirali elemente koje treba na odgovarajući način da spoje (sintetišu), pa su u nastavku uspešno rešavali zadatke. Kod jednog manjeg broja učenika (8\%) dešavalo se da i dalje nastoje da formiraju sliku od celih kocki, a ne od elemenata koji se nalaze na njima, te nisu uspevali u daljim zadacima.

I drugi istraživači zabeležili su slične postupke učenika prilikom rešavanja testa. Na primer, Kovačević (1986) je vršio ispitivanje na uzorku od 400 dece uzrasta od 1-4 razreda osnovne škole u Beogradu. U ovom istraživanju autor je 
definisao ponašanje ispitanika u rešavanju Kosovog testa na dva načina: konkretno i apstraktno. Jedna grupa ispitanika je pogledala model, birala boje, posmatrala gde koja boja treba da dođe. Oni su prvo razbijali model na elemente, a zatim tražili elemente i kombinovali ih. Za drugu grupu ispitanika može se reći da su koristili model pokušaja i pogrešaka. Oni su okretali kocke bez reda i plana i bili su više orijentisani na utisak celine modela, ne analizirajući ga. Dešavalo se da je u tom okretanju dete dolazilo do rešenja ali ga nije videlo, pa je i dalje okretalo kocke. Takvoj deci bila je potrebna konkretna pomoć (Kovačević, 1986). U istraživanju koje su obavili Rozencvajg i Fenuje (Rozencwajg \& Fenouillet, 2012) na uzorku od 90 ispitanika (uzrast od 12-17 godina) identifikovane su tri strategije ispitanika: globalne, analitičke i sintetičke. Rezultati su pokazali da su mlađi ispitanici češće koristili globalnu strategiju, a najmlađi su imali najviše poteškoća u rešavanju zadatka.

Isti autori zaključuju da je Kosov test sastavljanja kocki (Fenouillet \& Rozencwajg, 2015) težak za rešavanje, posebno na mlađim uzrastima, jer podrazumeva sposobnost ispitanika da izabere i koordinira funkcije koje će koristiti za rešavanje zadatka.

U pokušaju da podstaknemo razvoj analitičko-sintetičkog mišljenja kod učenika većina igara koje smo primenili su osmišljene tako da razvijaju sledeće misaone operacije: analiza elemenata situacije, njihovih veza i međusobnih odnosa, kao i organizacija principa u cilju razumevanja, uočavanje lika i podloge, celina i detalja, asocijativnih veza među njima, pronalaženje mogućih relacija između podataka, stvaranje relacija - dovođenje u odnos nepovezanih aspekata individualne stvarnosti (analiza i sinteza informacija ili kombinovanje elemenata sa ciljem stvaranja nove celine, restrukturiranjem stare). Kako bi učenici mogli da izučavaju i rešavaju određene pojave, moraju misaono, teorijski i praktično rastaviti tu pojavu na njene delove, činioce, aspekte, to jest analizirati pojavu sa krajnjim ciljem da se otkriju njihovi odnosi i funkcije. Pored toga, igre su podrazumevale i sintezu, odnosno, spajanje upoznatih i proučenih delova u odgovarajuću celinu. I pored primene navedenih igaranismo sa sigurnošću utvrdili zbog čega nije došlo do napretka učenika u eksperimentalnoj grupi, kada je reč o analitičko-sintetičkom mišljenju. Pretpostavljamo da odabrane igre nisu u dovoljnoj meri podsticale razvoj ovih sposobnosti, ili da, s druge strane, učenici nisu bili razvojno spremni da putem vežbanja razviju analitičko-sintetičko mišljenje na jedan viši nivo.

Iako primena sistema didaktičkih igara u nastavi nije dovela do napretka učenika eksperimentalne grupe po pitanju analitičko-sintetičkog mišljenja, treba pomenuti pozitivne strane ovog postupka. Aktivnosti koje su primenjene $\mathrm{u}$ eksperimentalnoj grupi, neprekidno su se preplitale, prožimale i dopunjavale uz 
stalan transfer specifičnih postupaka na intelektualne operacije opštijeg nivoa. Materijali su tako odabrani da su njima vežbane kvalitativno različite strukture mentalnih operacija. Naime, jednovremeno su iste operacije vežbane na raznovrsnim materijalima, a unutar pojedinih operacija bili su predviđeni postupci različiti po stepenu složenosti. Namera je bila da se učenici oslobode vezanosti za jedan ugao posmatranja i uobičajeni pristup činjenicama. Takođe, učenici su kroz igru usmeravani da predviđaju mogućnosti za rešavanje problema na osnovu elemenata koji im se nisu nalazili u vidnom polju, kao i da rešavaju probleme koji prevazilaze njihovo neposredno iskustvo, odnosno da se njihove aktivnosti internalizuju i prenose na misaoni plan na kome se strukturiraju pojmovi. Težilo se deperceptualizaciji, prelaženju sa činjeničkih na simboličke i logičke modele, odnosno, čitavim postupkom, učenici su stimulisani da u svojim operacijama apstrahovanja ne ostanu na fizičkom saznanju, već da izgrađuju više misaone nivoe.

Pored toga, učenici eksperimentalne grupe su, zahvaljujući samom načinu rada sa njima, bili veoma motivisani i angažovani zanimljivim i njima primerenim aktivnostima i materijalima. Nastavnici su potvrđivali da su učenici s nestrpljenjem iščekivali časove na kojima će se "igrati", te da su na ovim časovima imali mnogo manje problema sa disciplinovanjem učenika. Takođe, igre su doprinele socijalizaciji i razvoju govora kod učenika.

U ovom delu, smatramo da treba pomenuti i nedostatke ovog ispitivanja. Kada je reč o primenjenom postupku koji je izveden u okviru metoda igre, pretpostavljamo da odabrane igre nisu u dovoljnoj meri podsticale razvoj analitičko-sintetičkog mišljenja, ili s druge strane učenici nisu bili razvojno spremni da putem vežbanja razviju ove misaone sposobnosti na jedan viši nivo. Treba pomenuti da su prikazani rezultati deo šireg istraživanja koje se bavilo uticajem sistema didaktičkih igara na različite misaone sposobnosti kao što su sposobnost zaključivanja i nivo razvijenosti misaonih operacija: prepoznavanje, imenovanje, apstrahovanje, formiranje i definisanje. U ovim slučajevima, sistem didaktičkih igara je značajno uticao na pomenute misaone sposobnosti i operacije.

\section{ZAKLJUČAK I IMPLIKACIJE}

Istraživanje koje smo prikazali u ovom radu pokazalo je da primena sistema didaktičkih igara u radu sa učenicima eksperimentalne grupe nije dovela do poboljšanja uspeha učenika u sposobnosti analitičko-sintetičkog mišljenja. Podaci pokazuju da se nepostojanje razlike u inicijalnom ispitivanju na Kosovom testu sastavljanja kocki ponovilo i u finalnom, odnosno da među učenicima eksperimentalne i kontrolne grupe nema statistički značajne razlike u postignućima 
na ovom testu. Neke od razloga za dobijene rezultate na datom uzorku možemo pripisati osobenosti mišljenja učenika na uzrastu koji je ispitivan, a neki uzroci su svakako povezani sa sprovedenim postupkom, tačnije sa odabranim igrama koje su primenjene $u$ istraživanju. Pored toga, zabeleženi su i pozitivni efekti korišćenja igre u nastavnom procesu. Naime, primena sistema didaktičkih igara omogućila je stvaranje atmosfere koja je pružala uslove za razvijanje unutrašnjih motiva kod učenika kao što su radoznalost, traganje, doživljaj uspeha, istrajnost i sl., kao i angažovanje učenika na motornom, senzornom i misaonom planu.

Svakako je potrebno sprovoditi dalja istraživanja koja bi obuhvatila sledeće: ispitivanje mogućnosti delovanja metodom igre na usvajanje programskih sadržaja i ostvarivanje zadataka obrazovno-vaspitnog rada, standardizovanje testova kojima bi se mogla sa većom preciznošću meriti razvijenost misaonih sposobnosti, pre svega analitičko-sintetičkog mišljenja, proučavanje kombinacije metoda igre sa ostalim metodama, popularizovanje rezultata naučnih istraživanja u našim školama i osposobljavanje naših učitelja da ih prate i primenjuju u svojoj praksi, stvarajući tako potrebne uslove za dalji razvoj nastave.

Biljana Stojanović

\section{POSSIBILITIES OF DEVELOPING ANALYTICAL-SYNTHETIC THINKING OF STUDENTS USING A SYSTEM OF DIDACTIC GAMES}

\section{Summary}

This paper presents the results of the experimental application of a didactic games system with students of the first grade of primary school. The problem examined by the research was to determine whether and to what extent the process of the application of didactic games can influence the development of analytical-synthetic thinking among students. The aim of the research was defined as the possibility of encouraging the development of the analytical-synthetic thinking of students, using a system of didactic games. The study involved the use of a parallel-group experiment on a sample of 163 primary school pupils (6.5-7.5 years). After the initial examination of the students of the control and experimental group in order to determine whether the students were equal in terms of the level of analytical-synthetic thinking, a system of didactic games as a specific working procedure was introduced into the experimental group. The control groups' students followed the teaching materials in the usual way. The applied instrument is the Kohs block design test, which measures the analytical-synthetic ability of thinking. The results of the study showed that the didactic games system did not significantly affect the ability of the analyticalsynthetic thinking of students on the given sample, as there was no statistically significant difference between the students of the control and experimental groups in the final study. 
However, we did notice certain positive effects of the applied procedure in the students of the experimental group, such as: a positive and cooperative atmosphere in class, student satisfaction, high motivation for work, richer communication among pupils, etc. For these reasons, we think that it is necessary to consider the application of games in the teaching of materials, especially in the younger grades of the primary school.

Key words: didactic games, teaching, thinking skills, analytical-synthetic thinking, pupil, first grade.

\section{LITERATURA}

Bergen, D.G. - Mauer,D. (2000). Symbolic play, phonological awereness, and literacy skills at three age levels. In: Kathleen A. Roskos and James F. Chrisie (eds.), Play and literacy in early childhoods: Reaserch from multiple perspectives, pp.45-62. New York: Eribaum. ED 456904

Bodrova, E. - Leong,D. J. (2015). Vygotskian and Post-VygotskianViews on Children's Play,American Journal of Play, Vol 7, No 3, 371-388. doi.org/10.1017/CBO9780511816833.017

Bruner, J. (1986). Actual Minds, Possible Worlds. Massachusetts: Harvard University Press.

Conklin, H. (2014). Toward more joyful learning: integrating play into frameworks of middle grades teaching. American Educational Research Journal, 51(6), 1227-1255. DOI: $10.3102 / 0002831214549451$

Cook, D. (2000). Voice practice: Social and mathematical talk in imaginative play. Early Development and Care, 162, 51-63. EJ 610 324.DOI:10.1080/0300443001620105

Cutter-Mackenzie, A. - Edwards, S, - Moore, D., \& Boyd, W.(2014). Young Children's Play and Environmental Education in Early Childhood Education, Springer Briefs in Education, 9-24. DOI: 10.1007/978-3-31903740-0_2.doi.org/10.1504/ijlt.2011.042646

Ivić, I. (1964). Dečje mišljenje. Beograd: Rad.

Ivić, I. - Pešić, A. \& Antić, S. (2001). Aktivno učenje. Beograd: Institut za psihologiju.

Fenouillet, F. \& Rozencwajg, P. (2015). Visual-Spatial abilities and goal effect on strategies used to solve a block design task. Learning and Individual Differences, 39, 158-163.

Johnson, J. E. - Patte, M. (2013). Play: Commenting on Smith \& Pellegrini, Christie \& Roskos, Samuelsson \& Pramling, Baumer, Hart \& Tannock, 
Gosso \& Carvalho, Clark, and Jenvey, in Encyclopedia on Early Childhood Development. United Kingdom: University of London.

Jukić, S. (2005). Didaktičko-metodički fragmenti. Novi Sad: Viša škola za obrazovanje vaspitača, Vršac.

Kamenov, E. (1989). Intelektualno vaspitanje kroz igru. Beograd: Zavod za udžbenike i nastavna sredstva.

Kamenov, E. (2010). Mudrost čula. 2. deo, Razvijanje dečje inteligencije. Beograd: Zavod za udžbenike i nastavna sredstva.

Kohs, S. C. (1923). [doi:10.1037/11201-002 Intelligence measurement: A psychological and statistical study based upon the block-design tests], MacMillan Co. pp. 64-77.

Kovačević, P. (1986). Standardizacija Kohs-Goldsteinovog testa. Istraživanja u pedagoškoj psihologiji, Zbornik br. 2, Beograd, 55-63.

Kray, J. - Ferdinand, N. K. (2013). How to improve cognitive control in development during childhood: Potentials and limits of cognitive interventions. Child Development Perspectives, 7(2), 121-125. DOI: $10.1111 /$ cdep.12027

Lilard, A. S. (2014). The Development of Play. Lerner c11.tex V2 - Volume II 10/24/2014 5:45pm Page 425. DOI: http://dx.doi.org/10.1111/ hpb.12223_14

Lillard, A. S. - Woolley, J. D. (2014). Cognizing the unreal, Special Issue.Cognitive Development.Volume 34, 1-2. doi:10.1016/j.cogdev.2014.12.003

Lurija, A. R. (1976)._Osnovi neuropsihologije._Beograd: Nolit.

Maričić, S. - Špijunović, K. \& Lazić, B. (2016). Utjecaj sadržaja na razvijanje kritičkog mišljenja učenika u početnoj nastavi matematike. Croatian Journal of Education Hrvatski časopis za odgoj i obrazovanje, 18(1), 1140. doi:10.15516/cje.v18i1.1325

Millar, S. (1972). The Psyshology of Play. Harmondsworth: Penguin books.

Mishra, P. - Koehler, M. \& Henriksen, D. (2011). The seven trans-disciplinary habits of mind: Extending the TPACK framework flexibility with ideas for students - flexible thinking for their students Developing TPACK for 21st century teachers. Technology, 6(2), 146-163. doi.org/10.1504/ IJLT.2011.042646

Pederson, D. R. - Rook-Green, A. \& Elder, J. L. (1981). The role of action in the development of pretend play in young children. Developmental Psychology, 17 (6), 757-759.doi.org/10.1037/0012-1649.17.6.756 
Petrović-Sočo, B. (2014). Simbolička igra djece rane dobi. Croatian Journal of Education: Hrvatski časopis za odgoj i obrazovanje, 16 (Sp.Ed.1), 235251. Preuzeto s http://hrcak.srce.hr/117860

Pijaže, Ž. - Inhelder, B. (1978). Intelektualni razvoj deteta. Beograd: Zavod za udžbenike i nastavna sredstva.

Platz, D. - Arellano, J. (2011). Time tested early childhood theories and practices. Education,132 (1), 54-63.

Pramling Samuelson I. - Pramling, N. (2013). Play and learning. Smith PK, topic ed. In: Tremblay RE, Boivin M, Peters RDeV, eds. Encyclopedia on Early Childhood Development [online]. Montreal, Quebec: Centre of Excellence for Early Childhood Development and Strategic Knowledge Cluster on Early Child Development; 2013:1-6. Available at: http://www.childencyclopedia.com/documents/Pramling-Samuelson-PramlingANGxp1.pdf. Accessed June 4, 2015.

Pribišev Beleslin, T. (2013). Igra u istraživanjima s djecom. Croatian Journal of Education: Hrvatskičasopis za odgoj i obrazovanje, 16(Sp.Ed.1), 253-266.

Rozencwajg, P.- Fenouillet, F. (2012). Effect of goal setting on the strategies used to solve

a block design task. Learning and Individual Differences, 22, 530-536.

Rubinštajn, S. L. (1981). O mišljenju i putevima njegovog istraživanja. Beograd: Zavod za udžbenike i nastavna sredstva.

Saltz, E. - Dixon, D. \& Johnson, H. (1977). Training disadventages prescholers on various fantasy activites: Effects on cognitive functioning and impulse control. Child Development, 48 (2), 367-380.

Smith, P. K. - Dutton, S. (1979). Play and training in direct and innovative problem solving, Child Development, 50 (3), 830-836. EJ 212 936. DOI: $10.2307 / 1128950$

Taylor, M. (2013). Imagination. In: P. Zelazo (Ed.), The Oxford handbook of child development: Vol. 1. Body and mind (pp.791-831). New York, NY: Oxford University Press. DOI:10.1093/oxfordhb/9780195395761.001.0001

Thomas, L.-Warren, E. \& de Vries, E. (2011). Play-based learning and intentional teaching in early childhood contexts.Australasian Journal of Early Childhood, 36(4), 69-75.DOI:10.5172/ijpl.2011.97

Vygotsky, L. S. (1978). Mind in Society: The Development of Higher Psychological Processes. Cambridge, Massachusetts: Harvard University Press.

Wolfang, C. H.-Stannard, L. L. \& Jones, I. (2001). Block play performance among preschoolers as a predictor of later school achievement in mathematics. 
Journal of Research in Childhood Education, 15 (2), 173-180. EJ 629 993.DOI:10.1080/02568540109594958

Wood, E. (2010). Developing integrated pedagogical approaches to play and learning. In: P. Broadhead., J, Howard. \& E, Wood (Eds.), Play and learning in the early years. 132(1), 54-63. London: Sage Publications.doi.org/10.4135/9781473907850.n13

Wood, E. (2013). Play, learning and the early childhood curriculum ( $\left.3^{\text {rd }} \mathrm{ed}.\right)$. London: Sage Publications. 



\section{ПСИХОЛОГИЈА}


